\title{
VARIABILITY OF ANTHROPOMETRIC, ECHOCARDIOGRAPHIC AND BIOCHEMICAL INDICES WITH COMORBIDITY PATHOLOGY - ESSENTIAL HYPERTENSION AND TYPE 2 DIABETES
}

${ }^{1}$ Shalimova A.S. ${ }^{2}$ Belovol A.N., ${ }^{1}$ Kochueva M.N., ${ }^{3}$ Lutsyk V.L., ${ }^{3}$ Linskaya A.V.

${ }^{1}$ Kharkiv Medical Academy of Postgraduate Education, Ukraine; ${ }^{2}$ Kharkiv National Medical University, Ukraine;

${ }^{3}$ Institute of Neurology, Psychiatry and Narcology of NAMS of Ukraine

The mechanisms of development and progression of essential hypertension (EH) and concomitant type 2 diabetes (DM2) still remain not completely studied, so the comprehensive evaluation of the contribution of various indicators to the formation of this comorbidity have scientific interest.

The aim of this study was comprehensive assessment of the variability of anthropometric, echocardiographic and biochemical parameters in patients with EH and concomitant DM2.

Material and methods. We examined 243 patients aged 45-60 years. The main group consisted of 153 patients with EH stage II, grade 2 and DM2 moderate, subcompensated; comparison group - 70 patients with EH stage II, grade 2 without DM2. The control group consisted of 20 healthy individuals.

Methods: biochemical blood analysis, echocardiography evaluation of mitral diastolic blood flow and tissue Doppler spectral modes, reactive hyperemia, color Doppler mapping, enzyme immunoassay. Integrated data processing was carried out with the help of factor analysis using principal component.

Results and their discussion.

In the analysis there were 73 variables, based on the relationships among which there were 4 factors that together explain $52.61 \%$ of the total variability of the empirical data. In this case the first and the most powerful factor explained $33.07 \%$ of the total variability of indices (Table 1). Among the variables there were some constellations $41.17 \%$ of the fluctuations and changes observed in the empirical data, which were caused by two latent reasons of the highest level, that is the influence of two factors (and four factors explained more than half of the variation).

Table 1

Loads of the factors

\begin{tabular}{|c|c|c|c|c|}
\hline \multirow{3}{*}{ Indices } & \multicolumn{4}{|c|}{ Percents of variability indices } \\
\hline & 33,07 & 8,10 & 6,68 & 4,75 \\
\hline & Factor 1 & Factor 2 & Factor 3 & Factor 4 \\
\hline DC & 0,947 & & & \\
\hline MDA & 0,944 & & & \\
\hline TNF- $\alpha$ & 0,935 & & & \\
\hline $\mathrm{IL}-6$ & 0,933 & & & \\
\hline Blood glucose & 0,892 & & & \\
\hline HbAlc & 0,853 & & & \\
\hline HOMA & 0,851 & & & \\
\hline Leptin & 0,816 & & & \\
\hline Insulin & 0,815 & & & \\
\hline IMT & 0,751 & & & \\
\hline SOD & $-0,909$ & & & \\
\hline EDVD & $-0,873$ & & & \\
\hline Catalase & $-0,872$ & & & \\
\hline Adiponectin & $-0,795$ & & & \\
\hline HDL cholesterol & $-0,752$ & & & \\
\hline GFR & $-0,623$ & & & \\
\hline LVESV & & 0,95 & & \\
\hline LV ESD & & 0,947 & & \\
\hline LVEDV & & 0,931 & & \\
\hline LVEDD & & 0,923 & & \\
\hline LVMM & & 0,83 & & \\
\hline LV MMI & & 0,781 & & \\
\hline LVEF & & $-0,698$ & & \\
\hline $\mathrm{IL}-10$ & & & 0,825 & \\
\hline MAP & & & 0,624 & \\
\hline SBP & & & 0,619 & \\
\hline E/A & & & $-0,480$ & \\
\hline Weight & & & & 0,536 \\
\hline BMI & & & & 0,499 \\
\hline $\mathrm{s}$ & & & & 0,494 \\
\hline $\mathrm{E} / \mathrm{e}$ & & & & $-0,586$ \\
\hline $\mathrm{E}$ & & & & $-0,476$ \\
\hline PAP & & & 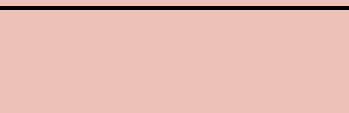 & $-0,469$ \\
\hline
\end{tabular}

Note: DC - diene conjugates, MDA - malondialdehyde, TNF- $\alpha$ - tumor necrosis factor- $\alpha$, IL- 6 - interleukin-6, HbAlc glycosylated hemoglobin, IMT - intima-media thickness of the common carotid artery, SOD - supperoxide dismutase, EDVD
- endothelium-dependent vasodilatation. HDL cholesterol - hich-density lipoprotein cholesterol. GFR - glomerular filtration - rate, IV ESV - left ventricle end-systolic volume, IV ESD - left ventricle end-systolic diameter, LV EDV - left vVtricle cont rate, LV ESV - left ventricle end-systolic volume, LV ESD - left ventricle end-systolic diameter, LV EDV - left ventricle end-
diastolic volume. LV EDD - left ventricle end-diastolic diameter, LV MM - left ventricle myocardial mass, LV MMI - left diastolic volume, LV EDD - left ventricle end-diastolic diameter, LV MM - left ventricle myocardial mass, LV MMI - left
ventricle myocardial mass index, LV EF - left ventricle ejection fraction, IL-10 - interlenkin-10, MAP - mean arterial

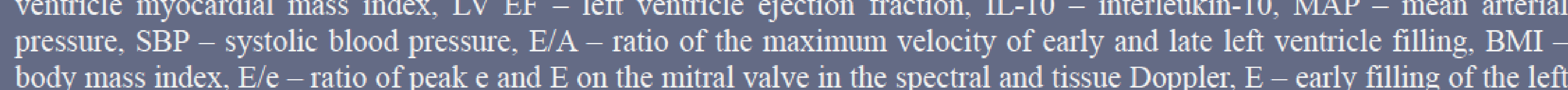
ventricle in spectral Doppler mode, PAP - average pulmonary artery pressure on Kitabatake.
The highest load of factor 1 were at indicators DC, MDA, TNF- $\alpha$, IL- 6 , blood glucose and insulin, HbAlc, HOMA, leptin, IMT, while at the negative pole of this factor were SOD, catalase, EDVD, adiponectin, HDL cholesterol, GFR.

At the next stage we investigated intensity of factors in groups of patients and reliability of differences in group factor estimates (Table 2). Including the variables for Factor 1, it was found that the patients with EH and contaminant DM2 had metabolic disorders with severe endothelial dysfunction, which significantly differed the main group from the group of control and comparison $(p<0,001)$.

Analysis of the second important Factor 2 showed that the patients with EH with and without DM2 had changes in LV geometry that reliably differed the main group and the comparison group from the control one.

Table 2

Averaged factor estimates and differences between the study groups on factors

\begin{tabular}{|c|c|c|c|c|c|}
\hline Groups & Factors & Averagged factor estimates & Couples comparison groups & $\begin{array}{l}\text { Significant differences } \\
\text { between group factor } \\
\text { estimates }\end{array}$ & $\begin{array}{l}\text { Distances } \\
\text { between groups }\end{array}$ \\
\hline \multirow{4}{*}{$\begin{array}{c}\text { Main study } \\
\text { group }\end{array}$} & Factor 1 & $0,517 \pm 0,025$ & \multirow{4}{*}{$\begin{array}{l}\text { Main study group - } \\
\text { Comparison group }\end{array}$} & Factor $1, \mathrm{p}<0,001$ & \multirow[b]{2}{*}{1,507} \\
\hline & Factor 2 & $0,071 \pm 0,062$ & & Factor $2, \mathrm{p}>0,05$ & \\
\hline & Factor 3 & $-0,057 \pm 0,040$ & & $\mathrm{Factor} 3, \mathrm{p}<<, 001$ & \\
\hline & Factor 4 & $-0,053 \pm 0,062$ & & Factor $4, p<0,05$ & \\
\hline \multirow{3}{*}{$\begin{array}{c}\text { Comparison } \\
\text { group }\end{array}$} & Factor 1 & $-0,986 \pm 0,039$ & \multirow{3}{*}{$\begin{array}{c}\text { Comparison group - Control } \\
\text { group }\end{array}$} & Factor $1, p<0,001$ & \multirow[b]{2}{*}{1,601} \\
\hline & Factor 2 & $-0,038 \pm 0,061$ & & Factor $2, \mathrm{p}<0,001$ & \\
\hline & $\begin{array}{l}\text { Factor } 3 \\
\text { Factor } 4 \\
\end{array}$ & $\begin{array}{l}0,978 \pm 0,059 \\
0.177 \pm 0,071\end{array}$ & & $\begin{array}{c}\text { Factor } 3, \mathrm{p}<0,001 \\
\text { Factor } 4, \mathrm{p}>0.05\end{array}$ & 3,229 \\
\hline \multirow{4}{*}{ Control group } & Factor 1 & $\begin{array}{l}-0,1 / 3 \pm 0,0711 \\
-2,476 \pm 0,037\end{array}$ & \multirow{4}{*}{$\begin{array}{l}\text { Main study group - Control } \\
\text { group }\end{array}$} & Factor $1, \mathrm{p}, \mathrm{p}<0,001$ & \multirow{2}{*}{3,072} \\
\hline & Factor 2 & $-0,623 \pm 0,083$ & & Factor $2, \mathrm{p}<0,001$ & \\
\hline & Factor 3 & $-2,249 \pm 0,070$ & & Factor $3, p<0,001$ & \multirow{2}{*}{2,194} \\
\hline & Factor 4 & $0,048 \pm 0,077$ & & Factor $4, \mathrm{p}>>0,05$ & \\
\hline
\end{tabular}

Figures 1 and 2 show the groups in coordinates «Factor 1 - Factor 2» and «Factor 3 Factor 4» respectively. Distances between the groups showed which groups and which factors differed the most from each other according to all the investigated parameters (the more the distances between the groups, the more pronounced differences the have). The main group differed the most from the control and comparison groups in the coordinate system «Factor 1 - Factor $2 »$, the differences related to Factor 1 were more considerable. The impact of Factor 3 with the patients with EH is shown by the more considerable distance from the comparison group to the control group in the coordinate system «Factor 3 - Factor 4» compared with the distance of the main group the control one correspondently (3.229 and 2.194 respectively).

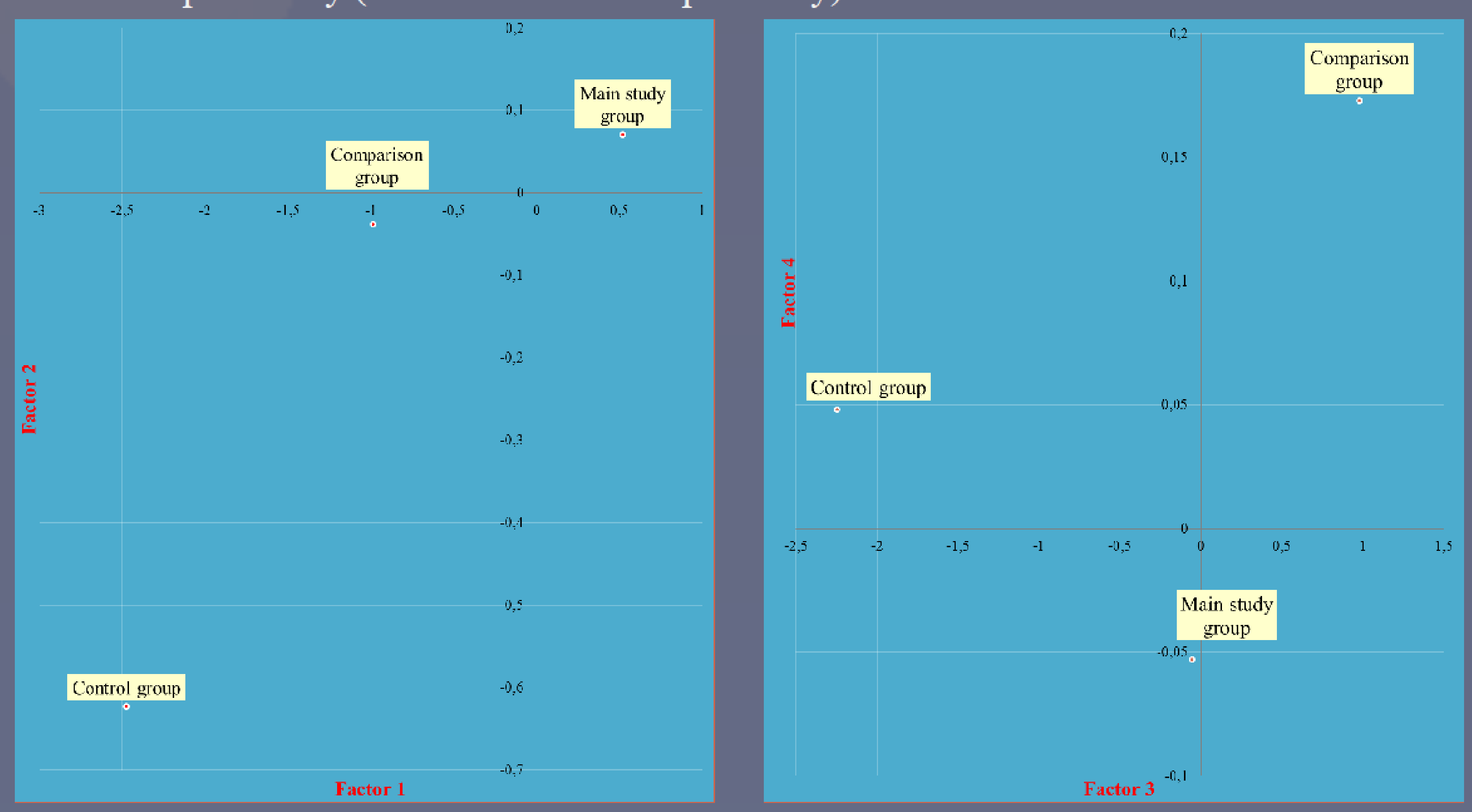

Figures 1 and 2

The group accommodation in the coordinate system «Factor 1 - Factor 2» and «Factor 3 - Factor 4» respectively

Conclusions

1. We discovered 4 main factors, the general action of which explained $52.61 \%$ of variability indices in comorbid pathology - EH and DM2.

2. Factor assessment of the most powerful Factor 1 with high significance made the studied groups of patients differ from each other.

References

Colwell J.A. Type 2 Diabetes, Pre-Diabetes, and the Metabolic Syndrome. JAMA, 2011; 306(2): 215

Dandona P., Aljada A., Chaudhuri A. et al. Metabolic syndrome: a comprehensive perspective based on interactions between obesity, diabetes, and inflammation. Circulation, 2005; 111: 1448-1454.

Montecucco F., Pende A., Quercioli A. et al.Inflammation in the pathophysiology of essential hypertension. J. Nephrol., 2011; 24: 23-34.

Ryden L., Standl E., Bartnik M. et al. Guidelines on diabetes, prediabetes, and cardiovascular diseases: executive summary. The task force on diabetes and cardiovascular diseases of the European Society of Cardiology (ESC) and of the European Association for the Study of Diabetes (EASD). European Heart J., 2007; 28(1): 88-137.

Shimamoto K., Miura T. Metabolic syndrome. Nippon Rinso, 2009; 67(4): 771-776.

Shoelson S.E., Lee J., Goldfine A.B. Inflammation and insulin resistance. J. Clin. Invest., 2006; 116(7): 1793-1801.

Tpriestersbach A., Röhrig B., du Prel J.B. et al. Descriptive Statistics The Specification of Statistical Measures and Their Presentation in Tables and Graphs. Part 7 of a Series on

42 Evaluation of Scientific Publications. Dtsch Arztebl Int., 2009; 106: 578-583.
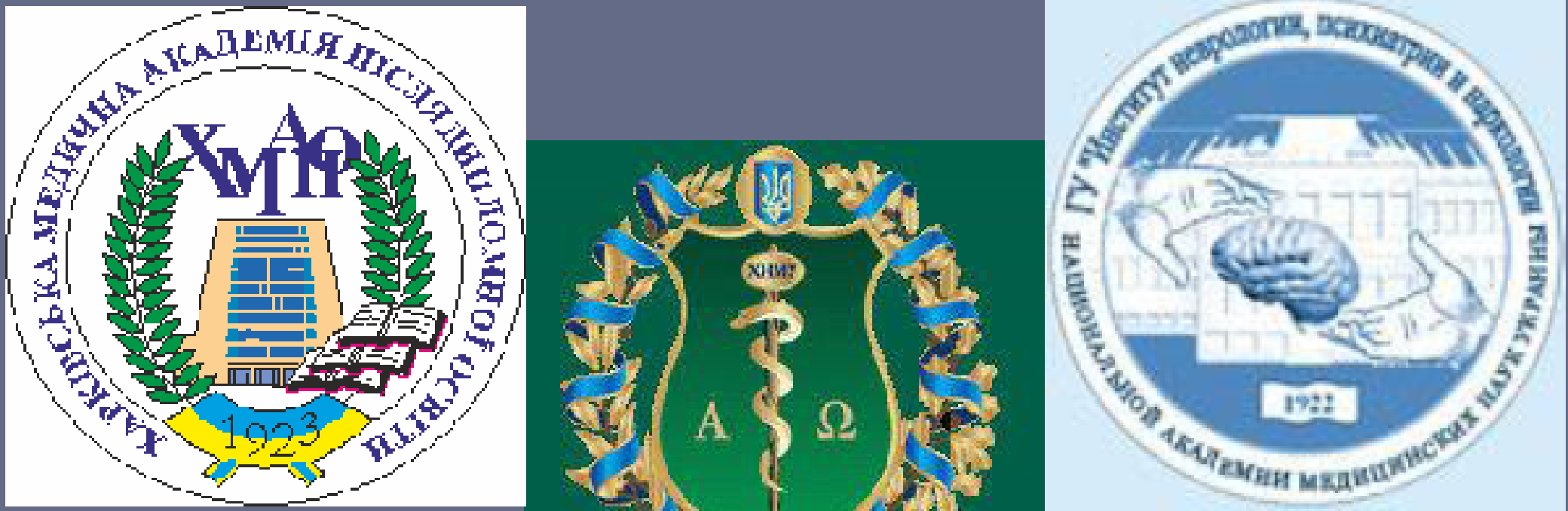

There is no conflict of interests 